\title{
The expression and regulation of Bcl-2-related ovarian killer (Bok) mRNA in the developing and adult rat testis
}

\author{
Janne S Suominen ${ }^{1}$, Wei Yan $^{1,2}$, Jorma Toppari ${ }^{1,2}$ and Antti Kaipia ${ }^{3}$ \\ Departments of ${ }^{1}$ Physiology and ${ }^{2}$ Pediatrics, University of Turku, Kiinamyllynkatu 10, 20520, Turku, Finland and ${ }^{3}$ Department of Surgery, \\ Satakunta Central Hospital, 28500, Pori, Finland
}

(Correspondence should be addressed to Jorma Toppari, Department of Physiology, University of Turku, Kiinamyllynkatu 10, FIN-20520, Turku, Finland; Email: jorma.toppari@utu.fi)

\begin{abstract}
Objective: To study the role of Bcl-2-related ovarian killer (Bok) in the regulation of apoptosis in the testis of developing and adult rat.

Methods: Bok mRNA expression was analyzed by Northern hybridization before and after culturing rat seminiferous tubules in vitro. Seminiferous tubules were cultured with different hormones and growth factors. Changes in the expression level of Bok mRNA during testicular development was analyzed by Northern hybridization. Localization of Bok mRNA was verified by in situ hybridization.

Results: Bok mRNA was highly expressed in the rat testis, varying during development. Highest expression levels were found in immature rats. Highest hybridization intensity appeared to be in spermatogonia, pachytene spermatocytes and Sertoli cells. Treatment with FSH was able to inhibit spontaneous increase of Bok mRNA expression that occurred in the defined stages of the rat seminiferous epithelium.

Conclusions: FSH protects germ cells from apoptosis and this protective effect may at least partly be due to the inhibition of Bok gene expression. The amount of apoptosis varies during testicular development and highest expression of Bok mRNA occurs at the time of apoptosis, suggesting a possible role for Bok in its regulation.
\end{abstract}

European Journal of Endocrinology 145 771-778

\section{Introduction}

A massive cell death occurs during spermatogenesis. It has been estimated that up to $75 \%$ of the hypothetical sperm number is lost due to cell death, which has been shown to be due to apoptosis (1-5). In mice, there are two peaks of apoptotic cell death during testicular germ cell development: the first around the 13th day of gestation and the second peak around the 10th day after birth (6). Our understanding of the molecular mechanisms of apoptosis has expanded recently, but the specific apoptotic machinery in germ cells is poorly understood (7).

The Bcl-2 family of proteins plays an important role in the control of apoptosis. It consists of both pro-survival (e.g. Bcl-2, Bcl-xL, Bcl-w, Mcl-1) and pro-apoptotic (e.g. Bok, Bcl-xS, Bax, Bak, Bad, Bik 1) proteins. They are related by homology and they operate via hetero- and homodimeric interactions $(7-10)$. It appears that the balance between death promoting and antagonizing proteins determines how a cell will respond to an apoptotic signal $(11,12)$.

The exact role of apoptosis-regulating $\mathrm{Bcl}-2$ gene products during spermatogenesis is unknown, but several lines of evidence suggest that it has to be important. Gene knock-out experiments of anti-apoptotic Bcl-w and pro-apoptotic Bax in mice lead to impaired spermatogenesis, suggesting that the balance of pro- and antiapoptotic mediators is crucial for the maintenance of spermatogenesis $(8,10,13)$.

Bok (Bcl-2-related ovarian killer) is a pro-apoptotic member of the Bcl-2 gene family. It was isolated from a rat ovarian fusion cDNA library by using the yeast two-hybrid system (14) and the mouse homolog (termed mtd) was found from the gene bank (15). In immature rats, the expression of Bok was found to be predominant in reproductive tissues, suggesting an important role for it in these tissues.

Bok expression has been studied in the ovaries (14) but its role in the testis is unknown. In the present study, our objective was to study the role of Bok in the regulation of apoptosis in the testis. We analyzed steady state levels of Bok mRNA in the developing and adult rat testis. Localization of Bok mRNA was performed by in situ hybridization. In addition, we studied the regulation of the Bok mRNA expression in the seminiferous tubules by reproductive hormones and growth factors. 


\section{Materials and methods}

\section{Experimental animals}

Sprague-Dawley rats of $0,5,10,21,41$ days and 2-3 months of age were housed in a constant temperature $\left(20^{\circ} \mathrm{C}\right)$ and light-darkness cycle (lights on, 0600$2000 \mathrm{~h}$ ) with free access to food and water. Ethylene dimethane sulfonate (EDS) was used to kill specifically Leydig cells in studies aiming to analyze hormonal regulation. The animals were injected i.p. with a single dose of EDS $(75 \mathrm{mg} / \mathrm{kg}$ body weight (BW)). EDS was synthesized as previously described (16) and dissolved in DMSO-water (1:3, vol./vol.). Control animals received injection of vehicle. Rats were killed on days 1, 2, 3, 4, 7, 10, 20 and 40 after EDS administration. Serum testosterone decreases to an undetectable level within $48 \mathrm{~h}$ and remains as such until day 10 after EDS treatment. Testosterone levels start to increase from day 20 onward and nearly reach control levels on day 40 (17). Most of the Leydig cells are depleted by apoptosis due to EDS treatment within $48 \mathrm{~h}$ (17).

Rats in all experiments were killed by $\mathrm{CO}_{2}$ asphyxiation, and different tissues were removed for subsequent analysis.

\section{Microdissection of the seminiferous tubules, tissue and cell culture and stimulation}

Testes were decapsulated and $5 \mathrm{~mm}$ seminiferous tubule segments were isolated under a transilluminating stereomicroscope. Stages of the seminiferous epithelial cycle were identified as described previously $(18,19)$. Microdissection and tissue culture experiments were performed in DMEM-Ham's F-12 medium (1:1; DMEM/F12; Life Technologies, Paisley, UK) supplemented with $15 \mathrm{mmol} / \mathrm{l}$ HEPES, $1.25 \mathrm{~g} / \mathrm{l}$ sodium bicarbonate, $10 \mathrm{mg} / \mathrm{l}$ gentamicin sulfate, $60 \mathrm{mg} / \mathrm{l}$ G-penicillin, $1 \mathrm{~g} / \mathrm{l}$ BSA and $0.1 \mathrm{mmol} / \mathrm{l}$ 3-isobutyl-1-methylxanthine (Aldrich Chemie, Steinheim, Germany). In tissue culture experiments, twenty $5 \mathrm{~mm}$ seminiferous tubule segments were incubated in the presence and absence of folliclestimulating hormone (FSH; $10 \mathrm{ng} / \mathrm{ml})$ (Organon, Oss, The Netherlands), testosterone $\left(10^{-7} \mathrm{~mol} / \mathrm{l}\right)$ (Sigma Chemical Co., St. Louis, MO, USA) and recombinant mouse stem cell factor (SCF; $100 \mathrm{ng} / \mathrm{ml}$ ) (Genzyme Transgenics Corp., Cambridge, MA, USA) for 8 or $30 \mathrm{~h}$. In cell culture experiments, we used MSC-1 cells, which are an immortalized Sertoli cell line derived from a testicular tumor of a transgenic mouse carrying a fusion gene composed of human anti-Müllerian hormone transcriptional regulatory sequences linked to the coding sequence of the SV40 virus T-antigen. Our MSC-1 cells were stably transfected with a cDNA plasmid encoding the rat FSH receptor (20). MSC-1 cells were incubated in DMEM, supplemented with gentamicin and 10\% fetal calf serum (Bioclear UK Ltd., Devizes, Wilts, UK).

\section{Preparation of cRNA probes}

The rat complementary DNA of Bok was cloned into pGEM4Z (Promega Corp., Madison, WI, USA). The cloned plasmid containing a $589 \mathrm{bp}$ insert, spanning nucleotides 46-635 of the published rat Bok cDNA, was linearized with HindIII or EcoRI restriction enzymes for the preparation of sense and antisense probes respectively. Control hybridization was made by using a $1.3 \mathrm{~kb}$ BamHI fragment of pI-19 cDNA clone of the mouse $28 S$ rRNA (21). In vitro transcription reactions were performed as recommended by the manufacturer (Promega). The radionuclides used were $\left[{ }^{35} \mathrm{~S}\right] \mathrm{UTP}$ (for in situ hybridization) and $\left[{ }^{32}\right.$ P]UTP (for Northern hybridization, Bok) and $\left[{ }^{32} \mathrm{P}\right]$ CTP (for Northern hybridization, 28S) (Amersham, Aylesbury, Bucks, UK). For in situ hybridization, sense and antisense RNA probes were adjusted to the same radioactivity $\left(1 \times 10^{5}\right.$ c.p.m. $\left./ \mu \mathrm{l}\right)$.

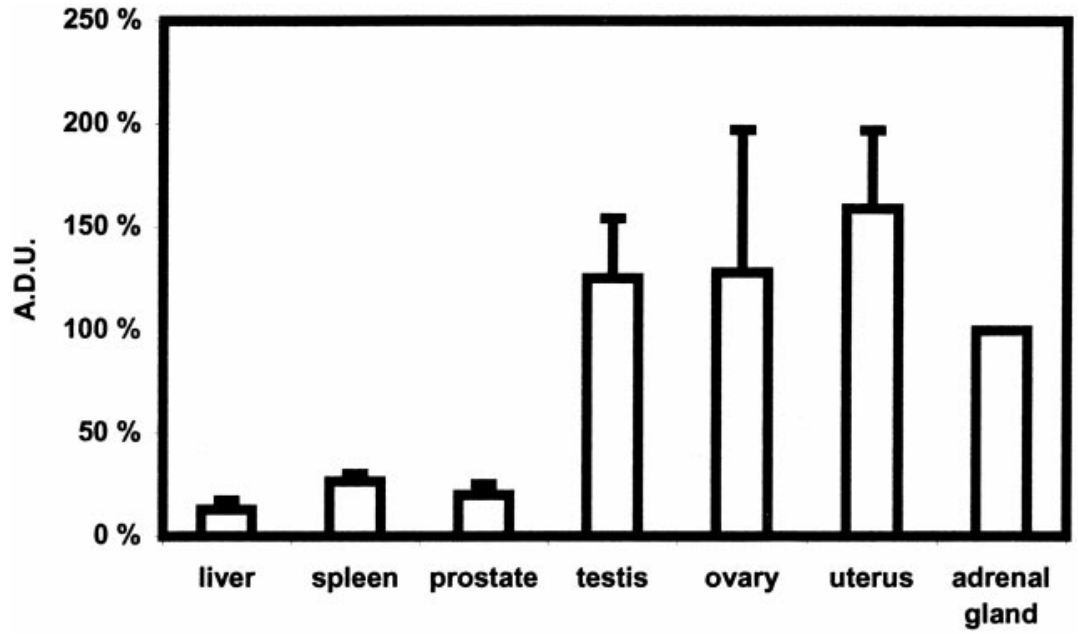

Figure 1 Expression of Bok mRNA transcripts in the rat tissues. The expression level in adrenal gland is designated as $100 \%$ and other values are expressed as percentages of it. Bok mRNA expression was found to be high in the adult rat testis, ovary, uterus and adrenal gland $(n=3)$. A.D.U., arbitrary densitometric units. 

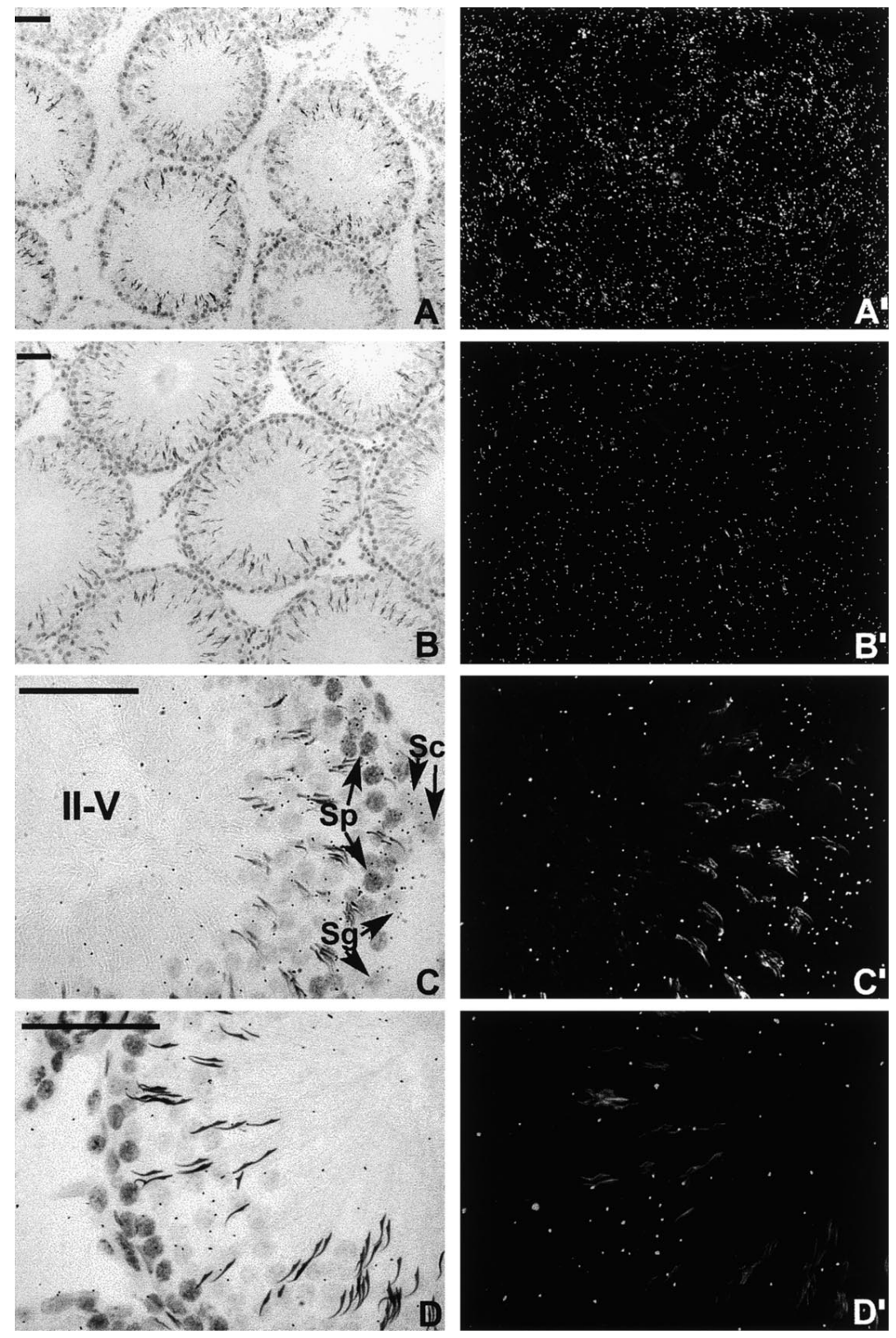

Figure 2 Localization of Bok mRNA in adult rat testis by in situ hybridization. The brightfield $(A-D)$ and corresponding darkfield $\left(A^{\prime}-D^{\prime}\right)$ photomicrographs of sections from an adult rat testis are shown. The specific signals $\left(A, A^{\prime}\right)$ are mainly confined to the layer where spermatogonia and meiotic cells are located. In high magnification $\left(\mathrm{C}, \mathrm{C}^{\prime}\right)$ the signals are mainly found to be confined to Sertoli cells (Sc), spermatogonia (Sg) and pachytene spermatocytes (Sp). The background signals were evaluated according to the sense probe $\left(B, B^{\prime}\right.$ and $\left.D, D^{\prime}\right)$. Note that bundles of elongated spermatids give auto-

fluorescent signals that do not represent any labeling. Bars, $50 \mu \mathrm{m}$.

\section{RNA extraction and Northern blot hybridization}

RNA extractions were made by using the single-step method (22). RNA was size-fractionated in denaturing $1 \%$ agarose gels. The gel was stained with ethidium bromide to verify an even loading of RNA. The RNA was transferred onto Hybond-N+ nylon membrane (Amersham). RNA was fixed to the membrane by u.v. cross-linking.

Filters were prehybridized in 50\% formamide, $3 \times$ SSC, $5 \times$ Denhart's solution $(1 \mathrm{mg} / \mathrm{ml}$ Ficoll, $1 \mathrm{mg} / \mathrm{ml}$ polyvinylpyrrolide and $1 \mathrm{mg} / \mathrm{ml} \mathrm{BSA),} \mathrm{1.2 \%} \mathrm{SDS,} \mathrm{10 \%}$ dextran sulfate, $1 \mathrm{mmol} / \mathrm{l}$ EDTA (Sigma) containing $10 \mu \mathrm{g}$ yeast transfer RNA at $65^{\circ} \mathrm{C}$ for $4-16 \mathrm{~h}$. Hybridization was performed at the same temperature for 14$24 \mathrm{~h}$ by adding the ${ }^{32} \mathrm{P}$-labeled probe. Filters were washed for $20 \mathrm{~min}$ with $2 \times \mathrm{SSC}-0.1 \%$ SDS at room temperature, followed by two washes in $0.2 \times \mathrm{SSC}-$ $0.1 \%$ SDS in $65^{\circ} \mathrm{C}$ for $20 \mathrm{~min}$ and two washes of $20 \mathrm{~min}$ in $0.1 \mathrm{SSC}-0.1 \%$ SDS at $65^{\circ} \mathrm{C}$. The filters were stripped after hybridization with Bok probe by pouring the boiling $0.1 \%$ SDS onto the filters. Control hybridization was done subsequently with mouse $28 \mathrm{~S}$ rRNA at $42^{\circ} \mathrm{C}$. Filters were exposed to Fuji Rx 100 film at $-70^{\circ} \mathrm{C}$ between intensifying screens. 

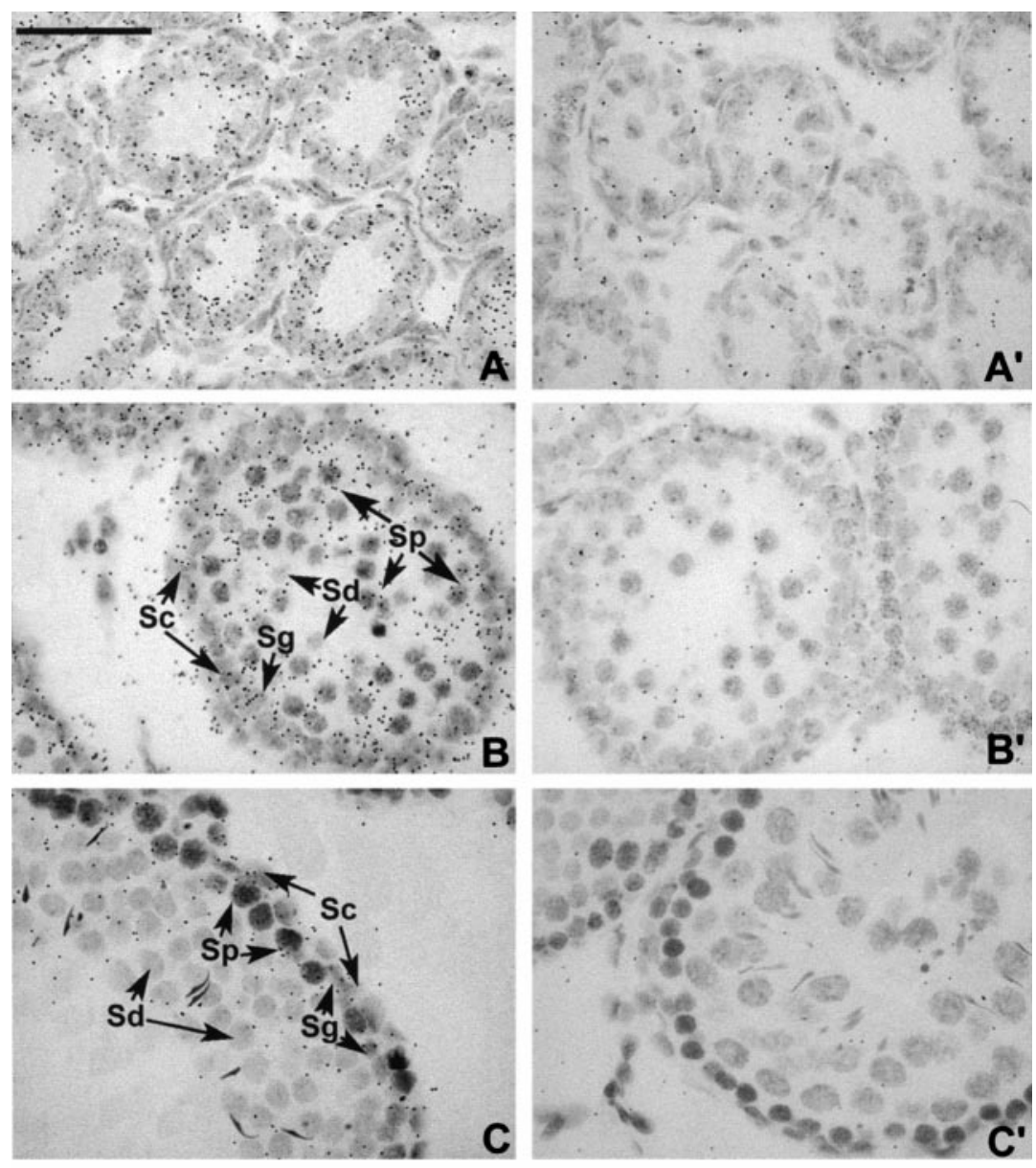

$28 \mathrm{~S}$

$18 \mathrm{~S}$

$1.5 \mathrm{~kb}$

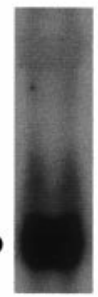

Bok
Figure 3 In situ hybridization of Bok mRNA in the immature rat testis using anti-sense probe is shown in the left panels $(A-C)$. The control hybridization with sense probe is on the right $\left(A^{\prime}-C^{\prime}\right)$. At $10(A)$ and $20(B)$ days of age, signals can be seen in Sertoli cells $(\mathrm{Sc})$, spermatogonia $(\mathrm{Sg})$ and pachytene spermatocytes $(\mathrm{Sp})$. Spermatids (Sd) do not show signals as shown in 20- and 40-day-old rat testis (C). Bar, $50 \mu \mathrm{m}$. Bok mRNA expression in the Sertoli cells was also verified by Northern hybridization analysis (D). The locations of the $28 \mathrm{~S}$ and $18 \mathrm{~S}$ ribosomal RNAs are marked on the left.

\section{Histology and in situ hybridization}

Testes were fixed in PBS-buffered $4 \%$ paraformaldehyde at $4{ }^{\circ} \mathrm{C}$ for $24 \mathrm{~h}$, dehydrated in ethanol, cleared in xylene, and embedded in paraffin. Five $\mu \mathrm{m}$ sections were cut, and in situ hybridization and autoradiography were performed as described previously (23).

\section{Densitometric analysis of Northern hybridization results}

The X-ray films of Northern hybridization were first scanned by a UMAX scanner (Super Vista S-20, Binuscan, Inc., Mamaroneck, NY, USA) and a Binuscan Photoperfect software package (Binuscan, Inc.). The images were saved as TIFFs $\left({ }^{*}\right.$.tif, Microsoft Corp. and
Aldus Co., New York, NY, USA) and then quantified by Tina 2.0 densitometric analytical system (Raytest Isotopenmesgerate $\mathrm{GmbH}$, Straubenhardt, Germany) according to the manufacturer's instructions.

\section{Statistical analysis}

In the Northern hybridization analyses, the densitometric values of the signals of Bok mRNA were first normalized to values obtained from the pI-19 control probe, to correct loading differences, then the highest densitometric value was designated $100 \%$. Other values were expressed as percentages of the highest one. The values from all experiments were pooled for calculation of the means and their s.E.M.s and for one-way ANOVA 


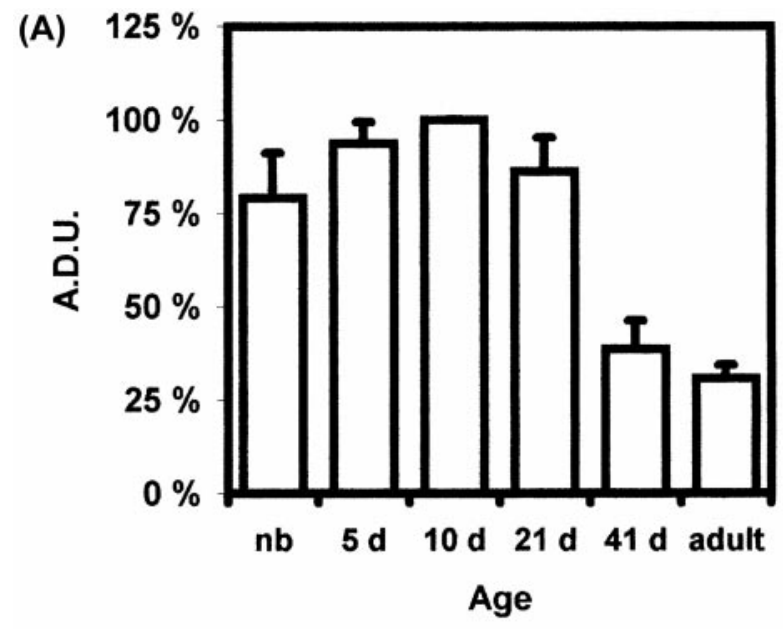

(B)

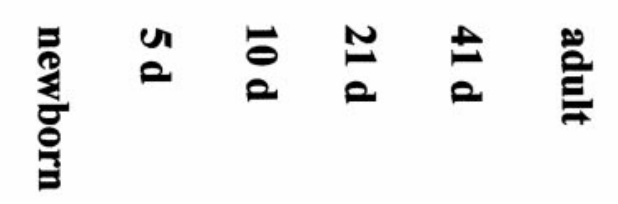

\section{$1.5 \mathrm{~kb}$}

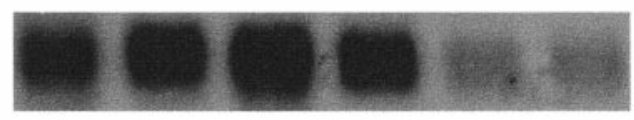

\section{EtBr}

Figure 4 (A) Bok gene expression during testicular development. Bok mRNA expression was found to be high during the first 21 days of life. Highest expression was found at 10 days after birth and it was designated as $100 \%$. The level of Bok mRNA expression during adult life was approximately one-third of the highest level. Each bar represents the mean \pm S.E.M. of three independent experiments. A.D.U., arbitrary densitometric units. (B) A representative Northern hybridization. EtBr, ethidium bromide.

and Tukey's post hoc test using SPSS 9.0 (SPSS Inc., Chicago, IL, USA). $P$ values less than 0.05 were considered statistically significant.

\section{Results}

\section{Expression of Bok mRNA transcripts in rat tissues}

Bok mRNA is widely expressed in the adult rat tissues. The expression levels were found to be high in adrenal gland, testis, ovary and uterus and Bok mRNA was expressed also in prostate, spleen, liver (Fig. 1) and heart, intestine, kidney, brain and lung (data not shown) analyzed by Northern hybridization.

\section{Localization of Bok mRNA}

The Bok gene was expressed in the compartment where spermatogonia and meiotic cells are located in the seminiferous tubules (Fig. 2). Highest hybridization intensity appeared to be in Sertoli cells, spermatogonia and pachytene spermatocytes (Fig. 2). Strong hybridization signals were seen during the early stages of testicular development (Fig. 3A). Bok mRNA expression in the Sertoli cells was verified also by Northern hybridization of mRNA isolated from MSC-1 Sertoli cell line (Fig. 3D).

\section{Bok gene expression during testicular development}

The highest level of Bok mRNA was found at 10 days after birth (Fig. 4). The expression was high from newborn to 21 days of age. Thereafter, it decreased and remained at a constant level.

\section{Hormonal regulation of Bok mRNA expression}

The steady state mRNA levels of Bok increased spontaneously about 2.5 -fold in stages IX-XII of the rat seminiferous epithelium during a 30-h incubation in vitro (Fig. 5). FSH stimulation inhibited the increase of Bok mRNA accumulation. In stages VII-VIII of the rat seminiferous epithelium FSH also showed some inhibition of Bok mRNA expression, but the effect was not statistically significant. Unlike FSH, SCF and testosterone failed to show any effect in the regulation of Bok mRNA levels.

\section{Effect of EDS treatment on Bok gene expression}

EDS causes a reversible decrease in the level of testosterone by killing the Leydig cells. The first apoptotic germ cells are shown to occur at day 3 (24). Steady state Bok mRNA levels were unaltered during the acute decrease of serum testosterone levels for the first $48 \mathrm{~h}$ after EDS administration (Fig. 6). On the third day after EDS administration, Bok mRNA expression dropped to approximately half of the control level. Seven days after EDS treatment the Bok mRNA levels were again comparable to those seen in the control.

\section{Discussion}

Bok is a novel member of the $\mathrm{Bcl}-2$ gene family and it was originally isolated from a rat ovarian fusion cDNA library (14). The mouse version of Bok cDNA, termed $\mathrm{mtd}$, has also been isolated (15). Because the expression of Bok mRNA was shown to be abundant in the immature female reproductive tissues, we anticipated that it might also have a role in the male reproductive physiology. The Bok mRNA expression was high in the adult rat adrenal gland, uterus and ovary. As expected, Bok mRNA was abundant also in the rat testis, suggesting that it may act as an apoptotic regulator during spermatogenesis. 


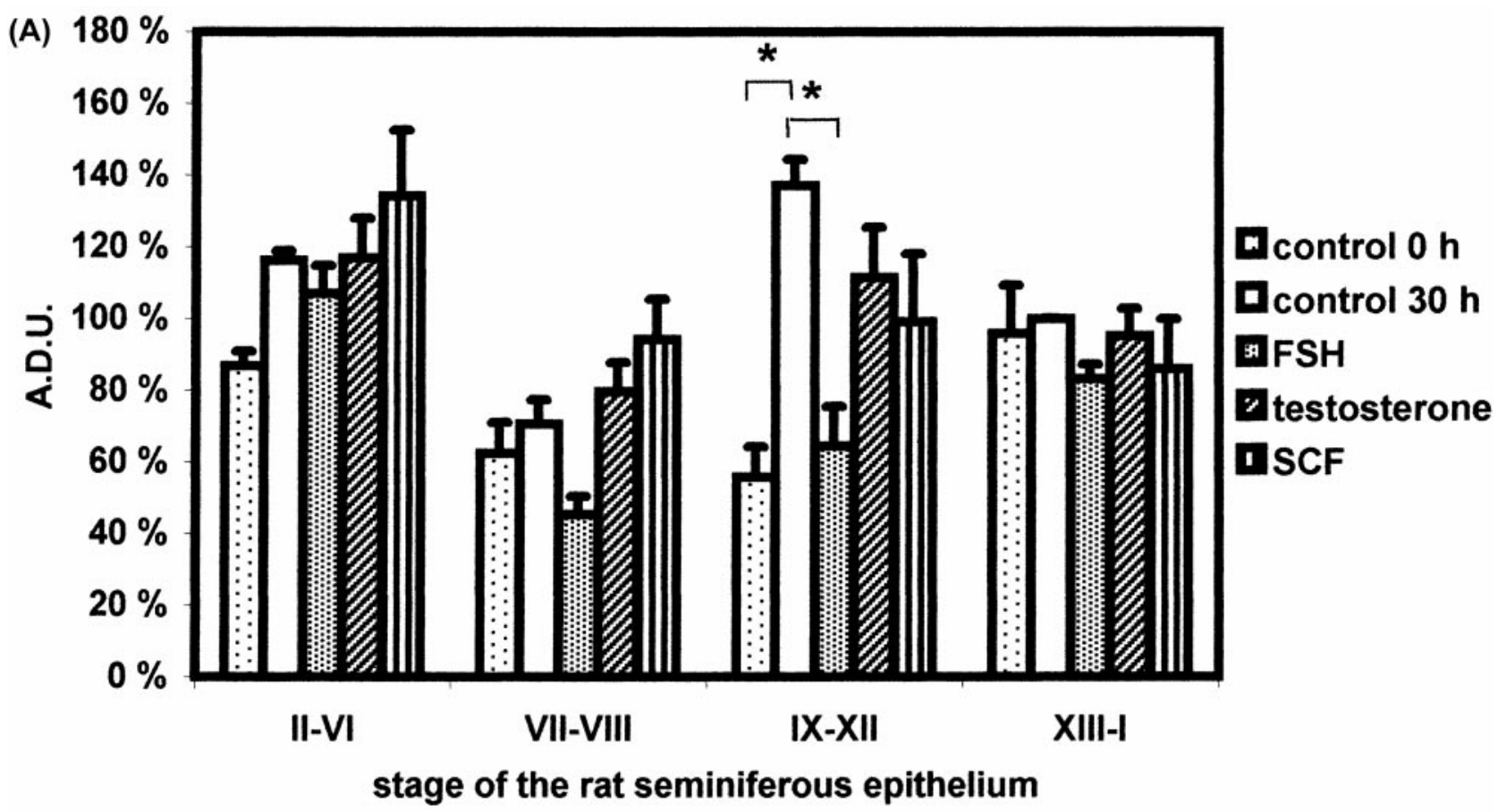

(B)

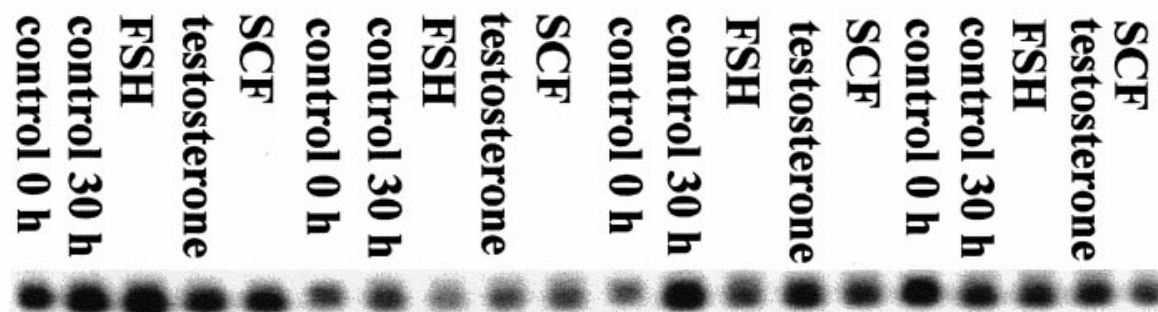

$1.5 \mathrm{~kb}$

EtBr

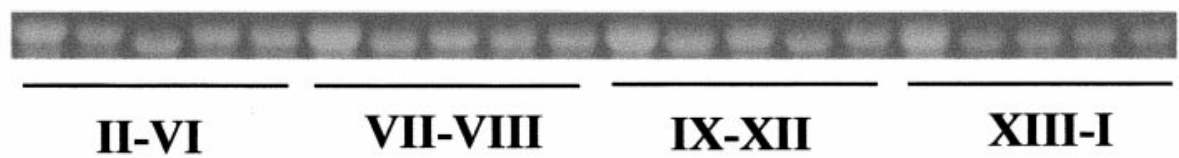

Figure 5 (A) Effect of FSH, testosterone and SCF on Bok gene expression. A spontaneous increase in the steady state level of Bok mRNA took place in stages IX-XII of the rat seminiferous epithelium during a 30-h culture in vitro. FSH stimulation inhibited the increase of Bok mRNA accumulation. SCF and testosterone did not show any effect on Bok mRNA levels. The expression level of Bok mRNA in stages XIII-I after 30-h stimulation in vitro was designated as $100 \%$. Statistical comparisons were made using ANOVA and Tukey's post hoc test. ${ }^{*} P<0.002$. Each bar represents the mean \pm S.E.M. of three independent experiments. A.D.U., arbitrary densitometric units. (B) A representative Northern hybridization. EtBr, ethidium bromide.

Northern hybridizations of testicular mRNA at different developmental stages showed that the level of Bok gene expression varies during testicular development. Highest expression was found at day 10 postnatally, when germ cell meiosis starts. Expression was high from newborn to day 21 when the first haploid cells appear (25). Also the amount of apoptosis varies during testicular development. The first apoptotic peak appears during prenatal development, when primordial germ cells immigrate into gonads. The second apoptotic peak occurs during the first round of spermatogenesis between days 10 and 20 of postnatal life (6). It has been suggested that the second apoptotic wave is required to maintain a proper cell ratio between maturing germ cells and Sertoli cells $(11,26)$. Disruption of this apoptotic peak by overexpressing Bcl-2 or Bcl-xL or by inactivating Bax or Bcl-w in the testis, results in sterility in mice $(8-11,13)$. The second apoptotic peak and the high expression of Bok mRNA occur at the same time, suggesting a possible role for Bok in this phenomenon. Similarly, in our previous studies, we have shown a similar expression pattern with proapoptotic proteins Bax and Bad, suggesting that they act in concert with Bok in order to maintain cellular homeostasis during this critical developmental stage (27). 


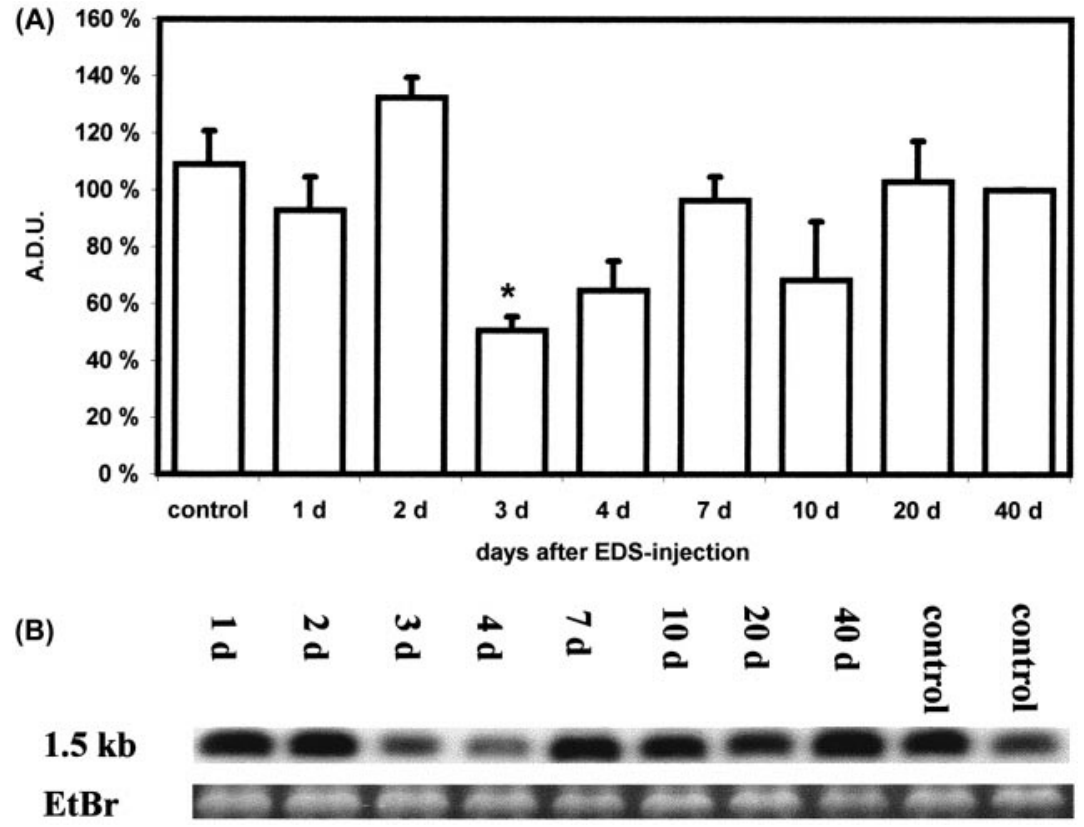

Figure 6 (A) Bok mRNA levels were on a constant level for the first $48 \mathrm{~h}$ after EDS administration. Steady state level of Bok mRNA decreased to approximately half on the third day. After 1 week Bok mRNA levels rose to the level seen in control animals. The expression level of Bok mRNA at 40 days after EDS injection was designated as $100 \%$. Statistical comparisons were made using one-way ANOVA and Tukey's post hoc test. ${ }^{\star} P<0.02$ compared with control. Each bar represents the mean \pm S.E.M. of three independent experiments. A.D.U., arbitrary densitometric units. (B) A representative Northern hybridization. EtBr, ethidium bromide.
In situ hybridization showed Bok mRNA expression predominantly in spermatogonia and primary spermatocytes. Spermatocytes are the major germ cell type undergoing apoptosis upon hormone withdrawal caused by gonadotropin-releasing hormone (GnRH) antagonist treatment (28). The expression of pro-apoptotic Bok in these cells indicates that it may be a constituent of the cellular apoptotic machinery in these spermatogenic cells. The decrease in Bok mRNA expression after 21 days of postnatal life probably reflects a relative decrease of spermatogonial and spermatocyte numbers as spermatogenesis progresses, rather than absolute decline.

We have shown previously that FSH and SCF can protect germ cells from apoptosis (29) and that FSH stimulation elevates SCF mRNA steady state levels during $30 \mathrm{~h}$ stimulation (30). In this study, we wanted to find out if Bok gene expression can also be regulated by these factors. A spontaneous increase of Bok mRNA expression in seminiferous tubule segments from stages IX-XII of the rat seminiferous epithelium was observed. Treatment with FSH inhibited the increase of Bok gene expression significantly, but SCF and testosterone failed to show a significant effect. Our previous observations on the hormonal regulation of germ cell apoptosis demonstrated that both FSH and SCF have a pro-survival effect and that FSH action is partially mediated by SCF (29). However, in this study, only FSH was able to regulate Bok expression, indicating that this effect was independent of SCF regulation. The protective effect of FSH on germ cells $(29,31)$ may at least partly be due to the inhibition of Bok gene expression.

Testosterone alone can maintain spermatogenesis, but for quantitatively normal sperm production, FSH is also needed (32-34). In vitro data showed no effect for testosterone in the regulation of the Bok gene. However, in an in vivo experiment, when testosterone-producing Leydig cells were depleted by EDS treatment, an acute fall in the intratesticular testosterone concentrations was reflected as decreased Bok mRNA expression. Therefore, it seems that FSH can regulate spermatogenesis by finetuning the expression of Bok and other pro-apoptotic Bcl-2 family proteins, while testosterone is the main driving force for ongoing spermatogenic processes.

In summary, we have studied the expression and hormonal regulation of Bok, a pro-apoptotic Bcl-2 family member in the adult and developing rat testis. The expression pattern of Bok suggests that it may act as a regulator of germ cell apoptosis during critical points of germ cell maturation in the immature and adult rat testis.

\section{Acknowledgements}

The authors thank Petri Ryhänen, MSc, for providing MSC-1 cells and Pirjo Pakarinen, PhD, for technical advice. This work was supported by grants from EU contracts QLRT-1999-01422 and the Academy of Finland, Research Programs on Environmental Health and Life 2000, Turku University Central Hospital and Satakunta Central Hospital.

\section{References}

1 Oakberg E. A description of spermatogenesis in the mouse and its use in analysis of the cycle of seminiferous epithelium and germ cell renewal. American Journal of Anatomy $195699391-413$.

2 Huckins C. The morphology and kinetics of spermatogonial degeneration in normal adult rats: an analysis using a simplified 
classification of germinal epithelium. Anatomical Record 1978190 905-926.

3 De Rooij DG \& Lok D. Regulation of the density of spermatogonia in the seminiferous epithelium of the Chinese hamster: II. Differentiating spermatogonia. Anatomical Record 1987217 131-136.

4 Allan DJ, Harmon BV \& Roberts SA. Spermatogonial apoptosis has three morphologically recognizable phases and shows no circadian rhythm during normal spermatogenesis in the rat. Cell Proliferation 199225 241-250.

5 Blanco-Rodriguez J \& Mertinez-Carcia C. Spontaneous germ cell death in the testis of the adult rat takes the form of apoptosis: reevaluation of cell types that exhibit the ability to die during spermatogenesis. Cell Proliferation 199629 13-31.

6 Wang RA, Nakane PK \& Koji T. Autonomous cell death of mouse male germ cells during fetal and postnatal period. Biology of Reproduction $1998 \mathbf{5 8} 1250-1256$.

7 Wylie C. Germ cells. Cell 199996 165-174.

8 Print CG, Loveland KL, Gibson L, Meehan T, Stylianou A, Wreford $\mathrm{N}$ et al. Apoptosis regulator Bcl-w is essential for spermatogenesis but appears otherwise redundant. PNAS 199895 12424-12431.

9 Furuchi T, Masuko K, Nishimune Y, Obinata M \& Matsui Y. Inhibition of testicular germ cell apoptosis and differentiation in mice misexpressing Bcl-2 in spermatogonia. Development 1996 $1221703-1709$

10 Knudson CM, Tung KSK, Tourtellotte WG, Brown GAJ \& Korsmeyer SJ. Bax-deficient mice with lymphoid hyperplasia and male germ cell death. Science 1995270 96-99.

11 Rodriguez I, Ody C, Araki K, Garcia I \& Vassalli P. An early and massive wave of germinal cell apoptosis is required for the development of functional spermatogenesis. EMBO Journal 1997 $162262-2270$

12 Oltvai ZN, Milliman CL \& Korsmeyer SJ. Bcl-2 heterodimerizes in vivo with a conserved homolog, Bax, that accelerates programmed cell death. Cell 199374 609-619.

13 Ross AJ, Waymire KG, Moss JE, Parlow AF, Skinner MK, Russell LD et al. Testicular degeneration in Bclw-deficient mice. Nature Genetics 199818 251-256.

14 Hsu SY, Kaipia A, McGee E, Lomeli M \& Hsueh AJW. Bok is a proapoptotic Bcl-2 protein with restricted expression in reproductive tissues and heterodimerizes with selective anti-apoptotic Bcl-2 family members. PNAS 199794 12401-12406.

15 Inohara N, Ekhterae D, Garcia I, Carrio R, Merino J, Merry A et al. Mtd, a novel Bcl-2 family member activates apoptosis in the absence of heterodimerization with Bcl-2 and Bcl-Xl. Journal of Biological Chemistry 1998273 8705-8710.

16 Jackson CM \& Jackson H. Comparative protective actions of gonadotrophins and testosterone against the antispermatogenic action of ethane dimethanesulphonate. Journal of Reproduction and Fertility 198471 393-401.

17 Yan W, Kero J, Huhtaniemi I \& Toppari J. Stem cell factor functions as a survival factor for mature Leydig cells and a growth factor for precursor Leydig cells after ethylene dimethane sulfonate treatment: implication of a role of the stem cell factor/c-kit system in Leydig cell development. Developmental Biology 2000227 169-182.

18 Parvinen M \& Vanha-Perttula T. Identification and enzyme quantitation of the stages of the seminiferous epithelial wave in the rat. Anatomical Record $1972 \mathbf{1 7 4} 435-450$.

19 Toppari J \& Parvinen M. In vitro differentiation of rat seminiferous tubular segments from defined stages of the epithelial cycle. Morphologic and immunolocalization analysis. Journal of Andrology $19856334-343$
20 Eskola V, Ryhänen P, Savisalo M, Rannikko A, Kananen K, Sprengel R et al. Stable transfection of the rat follicle-stimulating hormone receptor complementary DNA into an immortalized murine Sertoli cell line. Molecular and Cellular Endocrinology $1998139143-152$.

21 Arnheim N. Characterization of mouse ribosomal gene fragments purified by molecular cloning. Gene 19797 83-96.

22 Chomczynski P \& Sacchi N. Single-step method of RNA isolation by acid guanidinium thiocynate-phenol-choloroform extraction. Analytical Biochemistry 1987162 156-159.

23 Kaipia A, Penttilä TL, Shimasaki S, Ling N, Parvinen M \& Toppari $J$. Expression of inhibin $B_{a}$ and $B_{b}$ follistatin and activin-A receptor messenger ribonucleic acids in the rat seminiferous epithelium. Endocrinology $19921312703-2710$.

24 Henriksén K. Hakovirta H \& Parvinen M. Testosterone inhibits and induces apoptosis in rat seminiferous tubules in a stage-specific manner: in situ quantification in squash preparations after administration of ethane dimethane sulfonate. Endocrinology $19951363285-3291$.

25 Matsui Y. Regulation of germ cell death in mammalian gonads. Acta Pathologica Microbiologica et Immunologica Scandinavica 1998 $106142-147$.

26 Allan DJ, Harmon BV \& Kerr JFR. Cell death in spermatogenesis. In Perspectives on Mammalian Cell Death, pp 229-258. Ed. C S Potten. Oxford: Oxford University Press, 1987.

27 Yan W, Suominen J, Samson M, Jegou B \& Toppari J. Involvement of Bcl-2 family proteins in germ cell apoptosis during testicular development in the rat and pro-survival effect of stem cell factor on germ cells in vitro. Molecular and Cellular Endocrinology 2000 $165115-129$.

28 Billig H, Furuta I, Rivier C, Tapanainen J, Parvinen M \& Hsueh AJW. Apoptosis in testis germ cells: developmental changes in gonadotrophin dependence and localization to selective tubule stages. Endocrinology 1995136 5-12.

29 Yan W, Suominen J \& Toppari J. Stem cell factor protects germ cells from apoptosis in vitro. Journal of Cell Science 2000113 $161-168$.

30 Yan W, Linderborg J, Suominen J \& Toppari J. Stage-specific regulation of stem cell factor gene expression in the rat seminiferous epithelium. Endocrinology 1999140 1499-1504.

31 Henriksén K, Kangasniemi M, Parvinen M, Kaipia A \& Hakovirta $\mathrm{H}$. In vitro, follicle-stimulating hormone prevents apoptosis and stimulates deoxyribonucleic acid synthesis in the rat seminiferous epithelium in a stage-specific fashion. Endocrinology 1996137 $2141-2149$.

32 Singh J, O'Neill C \& Handelsman DJ. Induction of spermatogenesis by androgens in gonadotropin-deficient (hpg) mice. Endocrinology $19951365311-5321$.

33 Singh J \& Handelsman DJ. Neonatal administration of FSH increases Sertoli cell numbers and spermatogenesis in gonadotropin-deficient (hpg) mice. Journal of Endocrinology 1996 $15137-48$

34 McLachlan RI, Wreford NG, de Kretser DM \& Robertson DM. The effects of recombinant follicle-stimulating hormone on the restoration of spermatogenesis in the gonadotropin-releasing hormoneimmunized adult rat. Endocrinology 1995136 4035-4043.

Received 24 January 2001

Accepted 31 August 2001 